\title{
Dysfunction of Dendritic and $T$ Cells as the Cause of Immune Suppression in HTLV-I Infected Individuals
}

\author{
Ziyad Mutlaq Al-Dahoodi ${ }^{1)}$, Shigeki Takemoto', \\ Sayo Kataoka ${ }^{2)}$ and Hirokuni Taguchi ${ }^{11}$
}

Human T lymphotropic virus type I (HTLV-I) impairs cellular immunity and can develop into adult T cell leukemia/lymphoma (ATLL). The Role of dendritic cells (DC) has not been fully elucidated in individuals infected by HTLV-I. To address this issue, we studied several cellular parameters, including phenotypic and functional characteristics of monocyte-derived DC. Generated DC exhibited down-regulation in the expression of CDla and HLA-DR in HTLV-I carriers, suggesting partial impairment of maturation. $\mathrm{T}$ cells were stimulated by autologous DC in half of HTLV-I carriers, as well as healthy donors, but not in ATLL patients. Because of the importance of CD40-CD40 ligand (CD40L) signaling in establishing an inflammatory immune response, we also investigated the expression of soluble CD40L (sCD40L) of PHA-activated lymphocytes from HTLV-I infected individuals. SCD40L was detected in the culture supernatant of lymphocytes from one of four HTLV-I carriers investigated. These results suggest that the defect or aberration in the function of DC and the expression of SCD40L in T cells is associated with immune suppression in HTLV-I infected individuals.

\section{INTRODUCTION}

Human T lymphotropic virus type I (HTLV-I) is the cause of adult $\mathrm{T}$ cell leukemia/lymphoma (ATLL), and some non-malignant diseases ${ }^{1-3}$. During the asymptomatic stage of HTLV-I infection, the number of infected $T$ cells is probably restricted by viral antibodies and cytotoxic $\mathrm{T}$ lymphocytes $(\mathrm{CTL})^{4}$. However, once clonal proliferation of HTLV-I infected cells is detected following impairment of cellular immunity in HTLV-I carriers $^{5-7}$, ATLL develops in only a small portion. Dendritic cells (DC) are considered the most potent antigenpresenting cells (APC) and they can stimulate naive and memory $\mathrm{CD}^{+}$and $\mathrm{CD} 8^{+} \mathrm{T}$ cells. Inflammatory cytokines, such as IL-1 and tumor necrosis factoralpha (TNF- $\alpha$ ), as well as cell to cell contact with activated $T$ cells through CD40 ligand (CD40L)

Received : Oct 29, 2002

Revised: Nov 18, 2002

Accepted: Nov 22, 2002

${ }^{1}$ The Third Department of Internal Medicine, ${ }^{2}$ Medical Research Center, Kochi Medical School, Nankoku-city, Kochi 783-8505, Japan

Address correspondence and reprint request to Shigeki Takemoto, The Third Department of Internal Medicine, Kochi Medical School, Kohasu, Oko-cho, Nankoku-city, Kochi 783-8505, Japan induces DC to mature ${ }^{8-10}$. A recent study has shown that $\mathrm{CD} 40 \mathrm{~L}$ expression by $\mathrm{CD}^{+} \mathrm{T}$ cells is critical to elicit cell-mediated immune responses ${ }^{11}$.

Impaired APC function or the generation of inappropriate APC are possible mechanisms that lead to development of immune suppression. Compared to normal controls, phenotypic expression and function of monocyte-derived DC were impaired in diabetes mellitus and myelodysplastic syndrome patients ${ }^{12,13}$. Dysfunction of DC also has been reported in ATLL patients ${ }^{14}$. There is emerging evidence that malignant cells may be able to escape from anti-tumor immune responses by inhibiting the differentiation or the function of $\mathrm{APC}^{15,16}$. Because the role of DC has not been fully elucidated in HTLV-I carriers, we investigated monocyte-derived DC obtained from asymptomatic HTLV-I carriers, as well as from ATLL patients.

\section{MATERIALS AND METHODS}

\section{Patient samples and dendritic cell generation}

Peripheral blood was donated after informed consent by 4 patients diagnosed with ATLL ( 3 acute type and 1 lymphoma type), and 3 healthy donors at 
Kochi Medical School. A buffy coat fraction from 6 HTLV-I infected blood donors was prepared at Kochi Red Cross Blood Center and used for evaluation of asymptomatic HTLV-I carriers. We have no information on them.

Peripheral blood mononuclear cells (PBMC) were isolated from heparinized blood by densitygradient centrifugation using Ficoll-Hypaque and were used immediately or cryopreserved in liquid nitrogen until use, as described below. Monocytes were isolated with beads coated with anti-CD14 mAb (Dynabeads 450, Dynal, Oslo, Norway). Isolated monocytes were cultured at a density of $1 \times 10^{6}$ cells/ml in a RPMI-1640 medium for 5 days. The medium was supplemented with $2 \mathrm{mM}$ L-glutamine, $100 \mu \mathrm{g} / \mathrm{ml}$ of streptomycin, $100 \mathrm{U} / \mathrm{ml}$ of penicillin $\mathrm{G}$ and $10 \%$ heat-inactivated fetal bovine serum (FBS). $50 \mathrm{ng} / \mathrm{ml}$ of GM-CSF and $10 \mathrm{ng} / \mathrm{ml}$ of IL-4 (both from Sigma, Saint Louis, MO, USA) were supplied every two days. Maturation of differentiated DC was accomplished by treating with TNF- $\alpha$ $(10 \mathrm{ng} / \mathrm{ml})$ (Sigma) for another 2 days in the presence of IL-4 and GM-CSF. Cell differentiation was morphologically monitored after May-Giemsa staining.

\section{Flow cytometry analysis}

The surface phenotype expression of immature and mature DC was examined using a four color analyzer (FACSCalibur, Becton Dickinson, San Jose, CA, USA). The following commercially available directly conjugated monoclonal antibodies were used: CDla mAb, CD11c mAb CD40 mAb, CD80 mAb, CD86 mAb and HLA-DR mAb (all from eBioscience, San Diego, CA, USA). Appropriate isotype-matched negative controls were used for comparison. Viable cells $\left(1 \times 10^{4}\right)$ were gated and analyzed.

\section{Assay of endocytosis}

The ability of DC endocytosis was assessed using fluorescein isothiocyanate (FITC)-conjugated dextran (Sigma). After cells were harvested and re-suspended in RPMI-1640 medium, FITC-dextran (MW 40000) was added at a final concentration of 1 $\mathrm{mg} / \mathrm{ml}$. Cells were incubated at $37^{\circ} \mathrm{C}$ for $1 \mathrm{~h}$, washed four times with cold phosphate-buffered saline and analyzed by flow cytometry.

\section{Cell proliferation assay}

Autologous DC-lymphocyte mixed culture was conducted. Mature DC were harvested and used as stimulator cells after irradiation (30 Gy) (Gamma cell, Ontario, Canada). Autologous lymphocytes, after removal of monocytes from PBMC, were treated with purified phytohemagglutinin (PHA-P, $5 \mu \mathrm{g}$ ) $\mathrm{ml}$, Difco, Detroit, MI, USA) for 3 days and IL-2 (10 $\mathrm{U} / \mathrm{ml}$, kindly provided by $\mathrm{Dr} \mathrm{G}$ Franchini, NCI/ NIH, Bethesda, MD, USA) for another 4 days and used as responder cells. Stimulator and responder cells were plated in a ratio of $1: 10$ in 96-well round-bottom tissue culture plates (Costar, NY, USA). Proliferation of stimulator cells was completely blocked by irradiation. Cultures were maintained in a humidified atmosphere at $37^{\circ} \mathrm{C}$ and 5\% $\mathrm{CO}_{2}$. Thymidine incorporation was measured after 4-day incubation by pulsing for $18 \mathrm{~h}$ with 1 $\mu \mathrm{Ci} /$ well of ${ }^{3} \mathrm{H}$-thymidine. The results were expressed as the mean difference in counts per minute obtained from triplicate cultures using a liquid scintillation counter.

\section{Measurement of soluble CD40 ligand (sCD40L) in cell culture supernatants}

After positive selection of monocytes from PBMC, as described above, remaining lymphocytes and lymph node (LN) cells from lymphoma-type patients, as well as a MT-2 cell line, were cultured ( 1 x $10^{6}$ cells $\left./ \mathrm{ml}\right)$. Cells were stimulated with PHA-P $(5 \mu \mathrm{g} / \mathrm{ml})$ and cell-free supernatants were collected after $18 \mathrm{~h}$ and $48 \mathrm{~h}$ and stored at $-20^{\circ} \mathrm{C}$. They were analyzed by enzyme-linked immunosorbent assay (ELISA, Quantikine, R\&D System, Minneapolis, MN, USA, sensitivity $4.2 \mathrm{pg} / \mathrm{ml}$ ). The optical density was determined using a Thermomax microplate reader (Molecular Device Corp, Sunnyvale, CA, USA).

\section{RESULTS}

\section{Generation and maturation of DC}

Monocyte-derived DC were generated from the PBMC of healthy donors, asymptomatic HTLV-I carriers and ATLL patients. Although we had no information on HTLV-I carriers, we were able to isolate sufficient cells from the buffy coats supplied by Kochi Red Cross Blood Center to analyze DC, as well as lymphocytes. Efficient uptake of FITCdextran was found at an immature stage of DC in 
Normal
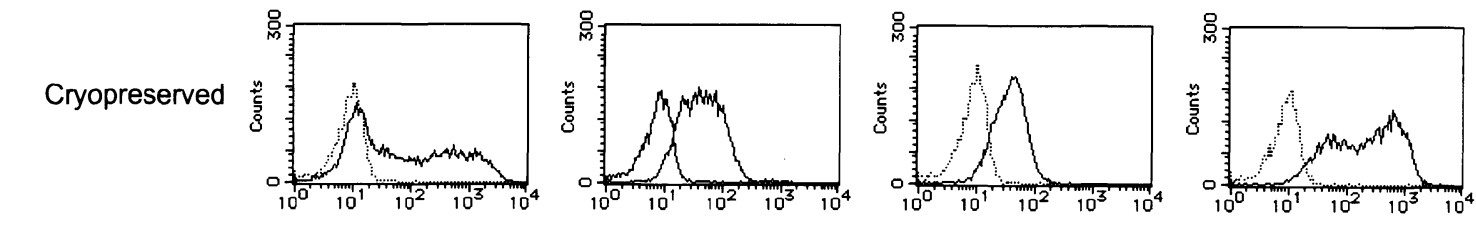

Asymptomatic

Carrier

Case 1
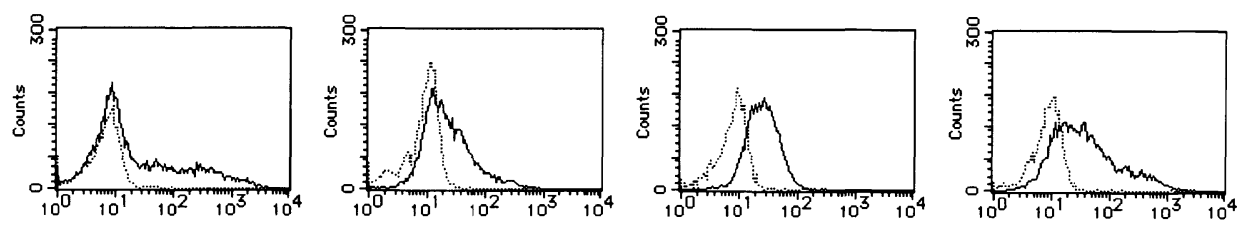

Case 2
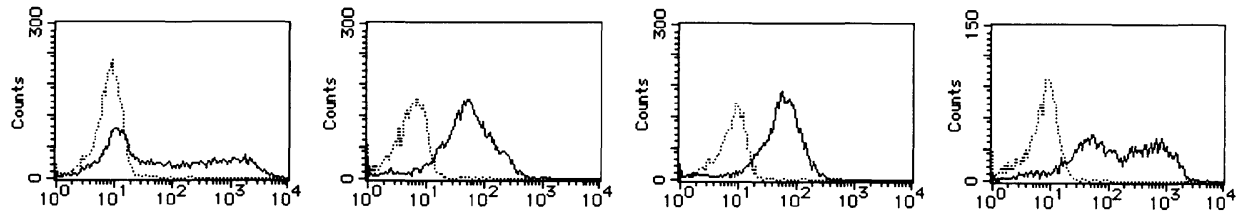

Case 3
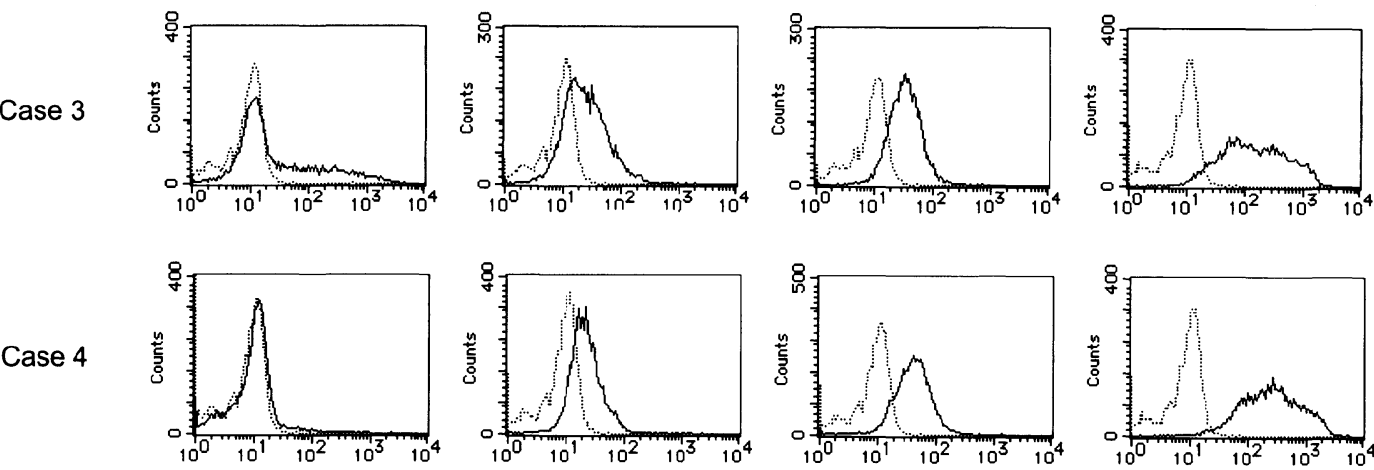

ATLL
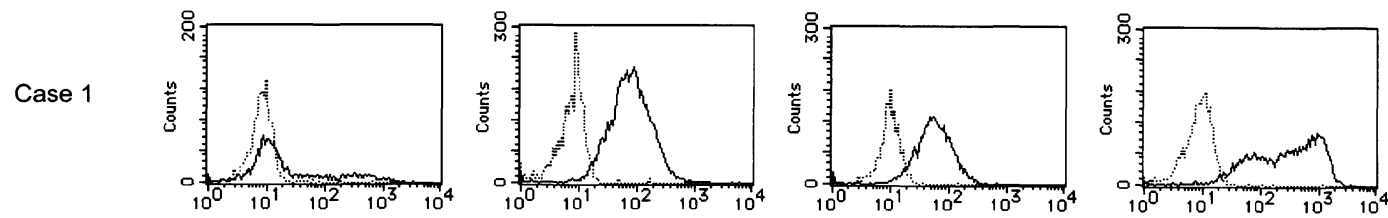

Case 2
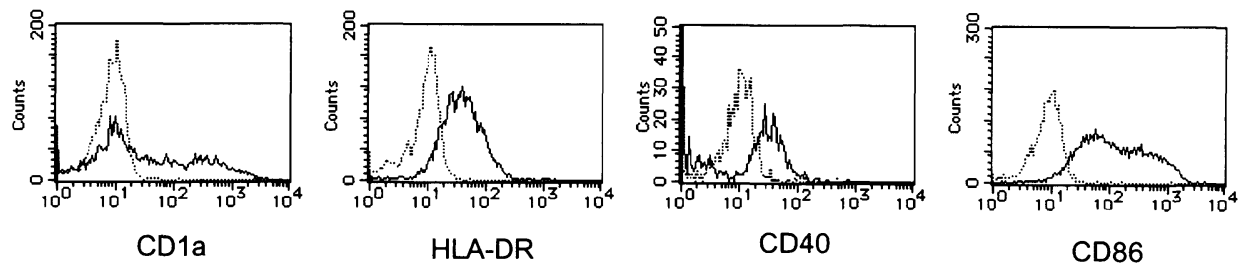

Fig. 1. Immunophenotypic characteristic of monocyte-derived mature DC obtained from a healthy donor, HTLV-I carriers and ATLL patients. The mature DC were differentiated by GM-CSF, and IL-4 for 7 days; TNF- $\alpha$ was added for the final 2 days. Monocytes were isolated using magnetic beads and stained with monoclonal antibodies $(\mathrm{mAb})$. (--) control $\mathrm{mAb} ;(-)$ specific $\mathrm{mAb}$.

asymptomatic carriers and ATLL patients (data not shown). The phenotypic feature of mature DC was examined by flow cytometry and Figure 1 shows representative results. There was no significant difference in the phenotype of mature DC from fresh and cryopreserved cells from healthy donors (data not shown). CDla expression was reduced in HTLV-I carriers and ATLL patients. Expression of HLA-DR was reduced in asymptomatic carriers. No substantial difference in the expression of CDIlc, CD40, CD80, or CD86 was detected between HTLVI infected individuals and healthy donors (data not 
shown).

\section{Aberrant stimulatory capacity of DC}

Comparative analyses have led to the suggestion that DC bear the unique ability to stimulate autologous $T$ cells in the autologous mixed lymphocyte reaction ${ }^{17-20}$. Therefore, autologous proliferation may be due to the presence of FBS and the reaction merely reflects a specific response to an exogenous antigen during the culture period. Because we confirmed that $\mathrm{T}$ cells proliferated with

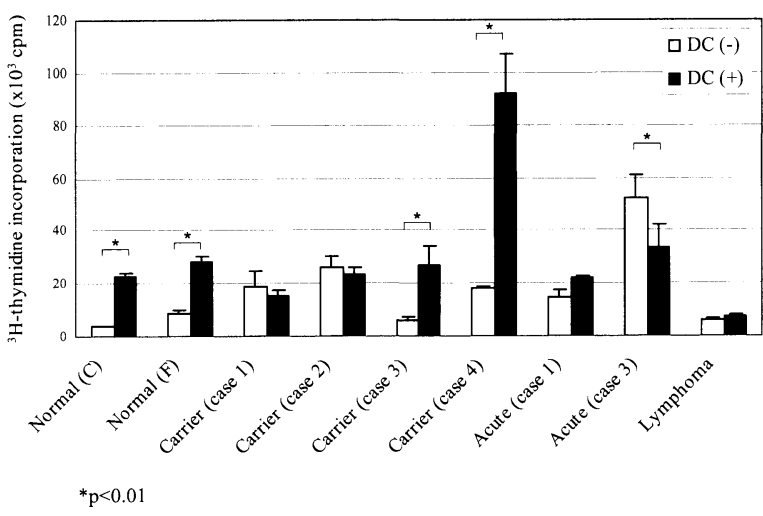

Fig. 2. Autologous mixed DC-lymphocyte reaction. Irradiated, mature DC (stimulator) were co-cultured with autologous lymphocytes (responder) at a $1: 10$ ratio. Healthy donor (C) and (F) indicate cryopreserved and fresh samples, respectively. Proliferation assays were performed in triplicate, and the mean $\pm \mathrm{SD}$ is shown. irradiated DC in the presence of $10 \%$ FBS but not $10 \%$ plasma (data not shown), the aberrant function of mature DC as APC was assessed by co-culture of lymphocytes with autologous DC (Fig. 2). T cells were stimulated by autologous DC in half of the HTLV-I carriers as well as in the healthy donors. Interestingly, $\mathrm{T}$ cells did not respond in ATLL patients and suppression of spontaneous proliferation of ATLL cells was observed in a patient with acute ATLL (case 3).

\section{Functional defect of $T$ cells}

To elucidate the other causes of immune suppression, $\mathrm{T}$ cell function was assayed by $\mathrm{sCD} 40 \mathrm{~L}$ expression. We compared several stimulators, including PHA-P, PMA $+\mathrm{Ca}^{2+}$ ionophore, anti-CD3 and anti-CD3+anti-CD28, and confirmed that PHA-P was the best stimulator for this experiment (data not shown). Following $18 \mathrm{~h}$ of activation with PHA-P, the production of SCD40L was detected in the supernatant of lymphocytes from 3 healthy donors and an asymptomatic carrier (case 6). Following $48 \mathrm{~h}$ of activation with PHA-P, the sCD40L concentration was elevated. The defect in the production of sCD40L was found in 3 of 4 asymptomatic carriers (cases 1,2 and 5), all ATLL patients and MT-2 (Table 1).

Table 1 Measurement of soluble CD40 ligand (sCD40L) in the culture sepernatant of lymphocytes after stimulation with PHA-P.

\begin{tabular}{lcc}
\hline \multicolumn{1}{c}{ Case } & After $18 \mathrm{~h}(\mathrm{pg} / \mathrm{ml})$ & After $48 \mathrm{~h}(\mathrm{pg} / \mathrm{ml})$ \\
\hline Healthy donors & & \\
Fresh & $193.6 \pm 155.5^{*}$ & $624.8 \pm 344.9^{*}$ \\
Cryopreserved & 177.6 & 320.5 \\
Asymptomatic carriers & & ND \\
Case 1 & ND & ND \\
Case 2 & ND & ND \\
Case 5 & ND & 177.6 \\
Case 6 & 75.9 & ND \\
ATLL patients (Acute type) & & ND \\
Case 1 & ND & ND \\
Case 3 & ND & ND \\
ATLL patient (Lymphoma-type) & & ND \\
(LN cells) & ND & ND \\
Cell line (MTphocytes) & ND & \\
\hline
\end{tabular}

*Average $\pm \mathrm{SD} ; \mathrm{ND}$, not detectable. 


\section{DISCUSSION}

Functional impairment of DC was demonstrated not only in ATLL patients but also in asymptomatic carriers. We found that CDla and HLA-DR expression was suppressed in asymptomatic carriers. Recent studies have identified the CD1 family as a non-classical antigen presenting molecule that enables presentation of foreign lipids for specific $\mathrm{T}$ cell recognition, which suggests a role in the activation of cell-mediated immunity ${ }^{21}$. Because IL-10 exhibited DC inhibition at a relatively late stage of DC maturation ${ }^{22}$, significant production of this cytokine might be associated with our findings ${ }^{23}$. Our results suggest that partial impairment of DC maturation from HTLV-I carriers may be a cause of immune suppression.

We observed proliferation of lymphocytes with autologous DC from healthy donors as FBS affected autologous MLR (Fig. 2). In contrast, lymphocyte proliferation was detected in half of the HTLV-I carriers and none of the ATLL patients. These findings suggest that functional impairment of DC as APC frequently occur in HTLV-I infected individuals. We also found that spontaneous proliferation of $\mathrm{T}$ cells was suppressed from acute-type ATLL, suggesting that activation induces $T$ cell death ${ }^{24}$. Because PHA triggered ATLL cell death in vitro, the spontaneous proliferation of ATLL cells may be due to $\mathrm{T}$ cell activation induced by cytokines or signaling via the CD3/TCR molecule complex (S. T., unpublished observations).

Like other members of the TNF super-family, activated $T$ cells can express both a membrane associated form and a soluble form of CD40L ${ }^{25}$. Both forms have the potential to be biologically active, and $\mathrm{SCD} 40 \mathrm{~L}$ can stimulate CD40 in a manner indistinguishable from the membrane-associated form of the protein ${ }^{26}$. It has been reported that $\mathrm{CD} 40 \mathrm{~L}$ expression is down regulated on $\mathrm{T}$ cells taken from ATLL patients ${ }^{27}$. We also observed a defect in the production of SCD40L in HTLV-I carriers, as well as in ATLL patients. CD40 expression by cognate DC was not necessary for initial $\mathrm{T}$ cell expansion but was essential to promote sustained expansion of $\mathrm{T}$ cells in $v_{i v o}{ }^{28}$. No autologous proliferation of $\mathrm{T}$ cells with DC was seen in T cells that did not express sCD40L (Fig. 2 and Table 1). It seems that CD40L/ CD40 interaction is important not only for DC maturation and activation but also for $\mathrm{T}$ cell proliferation in HTLV-I infected individuals. This defect may be exhibited as a result of immunosuppressive factors that negatively affect differentiation and terminal maturation of DC, as well as cellular immune response.

We showed that the maturation and function of DC as APC were frequently impaired in HTLV-I infected individuals. In addition, $\mathrm{T}$ cells from HTLV-I carriers expressed little CD40L. Immune suppression caused by such a network after HTLV-I infection may allow a small portion of infected cells to escape from the immune response as a prerequisite for the leukemogenesis. Further studies are required to determine the reason. Our findings suggest that phenotypic and functional defects of DC are associated with ATLL development in a small percentage of HTLV-I carriers who are regarded as at high risk for ATLL.

\section{ACKNOWLEDGMENTS}

We thank Kenji Nishimori for preparing the buffy coat fraction from blood donors. We thank Isao Miyoshi for his critical reading of the manuscript. This work was supported in part by Grantsin-Aid for Cancer Research from the Ministry of Education, Science and Culture of Japan (\# 12218104).

\section{REFERENCES}

1 Uchiyama T, Yodoi J, Sagawa K, Takatsuki K and Uchino $\mathrm{H}$ : Adult T-cell leukemia: Clinical and hematologic features of 16 cases. Blood 50:481492, 1977.

2 Hinuma $\mathrm{Y}$, Nagata K, Hanaoka M, Nakai M, Matsumoto T, Kinoshita K-I, Shirakawa S and Miyoshi I: Adult T-cell leukemia: Antigen in an ATL cell line and detection of antibodies to the antigen in human sera. Proc Natl Acad Sci USA 78: 6476-6480, 1981.

3 Franchini G: Molecular mechanisms of human T-cell leukemia/lymphotropic virus type I infection. Blood 86: 3619-3639, 1995.

4 Kannagi M, Sugamura K, Sato H, Okochi K, Uchino $\mathrm{H}$ and Hinuma $\mathrm{Y}$ : Establishment of human cytotoxic $\mathrm{T}$ cell Lines specific for human adult $\mathrm{T}$ cell leukemia virus -bearing cells. J Immunol 130 : 2942-2946, 1983.

5 Takemoto S, Matsuoka M, Yamaguchi $\mathrm{K}$ and Takatsuki K : A novel diagnostic method of Adult T-cell leukemia : Monoclonal integration of human T-cell lymphotropic virus type I provirus DNA detected by inverse polymerase chain reaction. Blood 84 : 3080-3085, 1994. 


\section{Z. M. Al-Dahoodi et al.}

6 Taguchi $\mathrm{H}$ and Miyoshi I : Immune suppression in HTLV-I carriers: A predictive sign of adult T-cell leukemia. Acta Med Okayama 43 : 317-321, 1989.

7 Tachibana N, Okayama A, Ishizaka J, Yokota T, Shishime E, Murai K, Shiori S, Tsuda K, Essex M and Muller N : Suppression of tuberculin skin reaction in healthy HTLV-I carriers from Japan. Int $\mathrm{J}$ Cancer 42: 829-831, 1988.

8 Witmer-Pack MD, Olivier W, Valinsky J, Schuler G and Steinman RM: Granulocyte/macrophage colony-stimulating factor is essential for the viability and function of cultured murine epidermal Langerhans cells. J Exp Med 166: 1484-1498, 1987.

9 Roake JA, Rao AS, Morris PJ, Larsen CP, Hankins DF and Austyn JM: Dendritic cell loss from nonlymphoid tissues after systemic administration of lipopolysaccharide, tumor necrosis factor, and interleukin 1. J Exp Med 181: 2237-2247, 1995.

10 Mackey MF, Gunn JR, Maliszewski C, Kikutani H, Noelle RJ and Barth Jr. RJ : Dendritic cells require maturation via CD40 to generate protective antitumor immunity. J Immunol 161 : 2094-2098, 1998.

11 Grewal IS and Flavell RA : CD40 and CD154 in cell-mediated immunity. Ann Rev Immunol 16: 111-135, 1998.

12 Takahashi K, Honeyman MC and Harrison LC: Impaired yield, phenotype, and function of monocyte-derived dendritic cells in humans at risk for insulin-dependent diabetes. J Immunol 161 : 2629-2635, 1998.

13 Rigolin GM, Howard J, Buggins A, Sneddon C, Castoldi G, Hirst WJR and Mufti GJ : Phenotypic and functional characteristics of monocyte-derived dendritic cells from patients with myelodysplastic syndromes. Br J Haematol 107 : 844-850, 1999.

14 Makino M, Wakamatsu S, Shimokubo S, Arima N and Baba $M$ : Production of functionally deficient dendritic cells from HTLV-I-infected monocytes: Implication for the dendritic cell defect in adult $\mathrm{T}$ cell leukemia. Virology 274: 140-148, 2000.

15 Chouaib S, Asselin-Paturel C, Mami-Chouaib F, Caignard A and Blay JY: The host-tumor immune conflict: from immunosuppression to resistance and destruction. Immunol Today 18: 493-497, 1997.

16 Menetrier-Caux C, Montmain G, Dieu MC, Bain C, Favort MC, Caux C and Blay JY: Inhibition of the differentiation of dendritic cells from $\mathrm{CD}_{3} 4^{+}$progenitors by tumor cells : Role of interleukin- 6 and macrophage colony-stimulating factor. Blood 92 :
4778-4791, 1998

17 Crow MK and Kunkel HG: Human dendritic cells : major stimulators of the autologous and allogenic mixed leukocyte reaction. Clin Exp Immunol 49: 338-346, 1982.

18 Thomas R, Davis SL and Lipsky PE : Isolation and characterization of human peripheral blood dendritic cells. J Immunol 150: 821-834, 1993.

19 Olweus J, BitMansour A, Warnke R, Thompson PA, Carballido J, Pecker LJ and Lund-Johansen F : Dendritic cell ontogeny: A human dendritic cell lineage of myeloid origin. Proc Natl Acad Sci USA 94: 12551-12556, 1997.

20 Buelens C, Bartholome JE, Amraoui Z, Boutriaux M, Salmon I, Thielemans K, Willems F and Goldman $\mathrm{M}$ : Interleukin-3 and interferon $\beta$ cooperate to induce differentiation of monocytes into dendritic cells with potent helper T-cell stimulatory properties. Blood 99: 993-998, 2002.

21 Porcelli SA : The CD1 system: Antigen-presenting molecules for $T$ cell recognition of lipids and glycolipids. Ann Rev Immunol 17 : 297-329, 1999.

22 Macatonia SE, Doherty TM, Knight SC and O' Garra A : Differential effect of IL-10 on dendritic cell-induced $\mathrm{T}$ cell proliferation and IFN- $\gamma$ production. J Immunol 150: 3755-3765, 1993.

23 Mori N, Gill PS, Mougdil T, Murakami S, Eto S and Prager D: Interleukin-10 gene expression in adult T-cell leukemia. Blood 88: 1035-1045, 1996.

24 Wesselborg S, Janssen $\mathrm{O}$ and Kabelitz D: Induction of activation-driven death (apoptosis) in activated but not resting peripheral blood $\mathrm{T}$ cells. J Immunol 150: 4338-4345, 1993.

25 Graf D, Muller S, Korthauer U, van Kooten C, Weise $\mathrm{C}$ and Kroczek RA: A soluble form of TRAP (CD40 ligand) is rapidly released after $\mathrm{T}$ cell activation. Eur J Immunol 25: 1749-1754, 1995.

26 Mazzei GJ, Edgerton MD, Losberger C, LecoanetHenchoz S, Graber P, Durandy A, Gauchat J-F, Bernard A, Allet B and Bonnefoy J-Y : Recombinant soluble trimeric CD40 ligand is biologically active. J Biol Chem 270: 7025-7028, 1995.

27 Makino M, Utsunomiya A, Maeda Y, Shimokubo $\mathrm{S}$, Izumo $\mathrm{S}$ and Baba $\mathrm{M}$ : Association of CD40 ligand expression on HTLV-I infected T cells and maturation of dendritic cells. Scand J Immunol 54 : 574-581, 2001.

28 Miga AJ, Masters SR, Durell BG, Gonzalez M, Jenkins MK, Maliszewski C, Kikutani $\mathrm{H}$, Wade WF and Noelle RJ : Dendritic cell longevity and T cell persistence is controlled by CD154-CD40 interactions. Eur J Immunol 31: 959-965, 2001. 